\title{
BIOLOGICAL RESISTANCE OF HEAT-TREATED WOOD OF Pinus caribaea AND Eucalyptus saligna
}

\author{
José Otávio Brito ${ }^{1, \star}$, Ananias Francisco Dias Júnior ${ }^{2}$, Artur Queiroz Lana ${ }^{1}$, Carlos Rogério Andrade ${ }^{3}$, \\ Francisco Fernandes Bernardes ${ }^{1}$
}

\begin{abstract}
This study aimed to analyze the resistance of the thermally treated wood of Pinus caribaea and Eucalyptus saligna to the biological attack of wood rotting fungi. The heat treatment processes were carried out in electric oven under nitrogen atmosphere, starting from $100^{\circ} \mathrm{C}$ until reaching each one of the final temperatures of the process: $120,140,160$, and $180^{\circ} \mathrm{C}$. The resistance assays were performed for white rot, brown rot, and soft rot fungi. The increase in decay resistance was observed for heat-treated wood of Pinus caribaea at higher temperatures. On the other hand, Eucalyptus saligna showed increased resistance to rotting fungi at all tested temperatures, except for white and soft rot at $120^{\circ} \mathrm{C}$. In general, the heat treatment process showed good results for its use as a wood preservative method.
\end{abstract}

Keywords: Brown-rot fungi, decay fungi, soft-rot fungi, thermally treated wood, white-rot fungi, wood preservation, wood heat treatment.

\section{INTRODUCTION}

Wood is an organic material subject to attack by various biological agents, including fungi, termites, insects, bacteria, marine organisms, etc. These organisms recognize the natural polymers of wood cell wall as a source of food, having specific enzyme systems capable of metabolizing them into digestible units. Then, to expose the wood to adverse conditions like increased soil contact, it is necessary to select species of high natural durability or those treated with chemical preservatives that significantly increases the life, making it more resistant to the attack of xylophagous organisms (Vivian et al. 2015).

The treatments of wood using chemical or biological agents aim at the preservation of the cellular wall of the wood, without modifying its intrinsic nature. Throughout history, the problem is that there have been noted some obstacles in this practice, such as toxicity and aggressiveness to the environment and life forms, difficulty in impregnating certain woods, and loss by leaching of the preservatives (Ferrarini et al. 2012).

Heat treatment has been approached as a wood preservation technique. As an example in Europe, heat application has been a widespread practice to improve physical properties of wood in conifers species like spruce (Picea abies) (Alén et al. 2002) and hardwood like poplar (Populus robusta) (Rousset et al. 2004), and biological resistance has been improved in woods, such as Scots pine (Pinus sylvestris) and Norway spruce (Picea abies), by evaluating the use of rot fungi such as Coniophora puteana and Poria placenta (Metsä-Kortelainen et al. 2005). The heat treatment is the basic process where an intermediate product is obtained between wood and charcoal, having some comparative advantages over the original material, including decrease in

\footnotetext{
${ }^{1}$ Universidade de São Paulo / Escola Superior de Agricultura "Luiz de Queiroz" - Laboratórios Integrados de Química, Celulose e Energia (LQCE/USP/ESALQ), Piracicaba, Brazil.arturqlana@usp.br; franciscobernardes@usp.br

${ }^{2}$ Universidade Federal do Espírito Santo, Departamento de Ciências Florestais e da Madeira (DCFM/UFES), Jerônimo Monteiro, Brazil. ananias.dias@ufes.br

${ }^{3}$ Universidade Federal de Goiás (UFG), Jataí, Brazil. cra.florestal@yahoo.com.br

•Corresponding author: jobrito@usp.br

Received: 04.03.2016 Accepted: 05.10.2018
} 
hygroscopicity, increase in dimensional stability, etc. (Brito 1992, Pincelli et al. 2002, Palermo et al. 2015).

Regarding the chemical composition of wood, Batista et al. (2016), studying the thermal treatment of eucalyptus at 140,160 , and $180^{\circ} \mathrm{C}$, verified that the chemical composition of the Eucalyptus grandis juvenile wood was significantly altered by the heating process. Studies indicate that heat-treatment causes, fundamentally, the partial degradation of hemicellulose (Brito et al. 2006, Brito et al. 2008, Garcia et al. 2012). In addition to the degradation of hemicellulose, there are references to the breaking of free hydroxyl groups of the amorphous region of cellulose and reticulation of polymers that make up the wood during this treatment (Weiland and Guyonnet 2003, Rousset et al. 2004, Wikberg and Maunu 2004). In general, the heat treatment can be defined as a process that promotes the unavailability of hemicellulose, which serves as food for fungi. The heat-treatment reduces the equilibrium moisture content, which is a key factor for the growth of organisms. The wood heating process also promotes the creation of new free molecules that may act as fungicides and insecticides and a crosslink in lignin network that make it difficult to recognize substrates by xylophagous organisms such as fungi and termites (Weiland and Guyonnet 2003).

In addition, there are differences in the behavior of conifers and hardwoods when treated thermally. Studying the thermal stability of klason lignin, Poletto (2017) observed that Pinus taeda lignin is thermally more stable than those of the Eucalyptus grandis, stating that it is probably due to the higher thermal stability of the guaiacyl units in soft wood lignin. This suggests that heat-treated wood from conifers and hardwoods may have different behaviors when attacked by biological agents.

Given the information above, this study aimed to evaluate the resistance of xylophagus fungus attack in Pinus caribaea and Eucalyptus saligna heat-treated at different temperatures, contributing to the knowledge of less toxic and environmentally friendly techniques for the increase of wood durability.

\section{MATERIAL AND METHODS}

The wood material used for the study was 25-year-old Pinus caribaea with a specific mass of $497 \mathrm{~kg} / \mathrm{m}^{3}$ and 20-year-old Eucalyptus saligna with a specific mass of $579 \mathrm{~kg} / \mathrm{m}^{3}$ from commercial areas of the companies Duratex in the city of Agudos and Eucatex in the city of Salto, both in São Paulo, Brazil.

For this experiment, twenty samples of each species were randomly harvested, selecting four-meter-long logs with a minimum diameter of $25 \mathrm{~cm}$. Then, the logs were sawed into planks with dimensions of $400 \times 40$ x $7 \mathrm{~cm}$ and stored in a shed with approximately $70 \%$ relative humidity at $24{ }^{\circ} \mathrm{C}$, for natural drying for four months. The boards were reprocessed to obtain samples of $60 \times 20 \times 5 \mathrm{~cm}$ to be taken to a climatic chamber (temperature of $25^{\circ} \mathrm{C}$ and $65 \%$ R.H.) until they reach $15 \%$ of moisture content for conducting the subsequent assays.

\section{Heat treatment process}

The samples of both species were dried in an electric oven with air circulation for twenty-four hours in each of the following temperatures: 60,80 , and $100{ }^{\circ} \mathrm{C}$. In the end the samples were between 3 and $4 \%$ moisture content.

For heat treatment process, the wood samples were arranged to maximize surface area inside an electric oven with programmed temperature and time (Figure 1). The oven environment was saturated with nitrogen gas with an initial process temperature of $100{ }^{\circ} \mathrm{C}$ and heating rate of $0,033{ }^{\circ} \mathrm{C} \mathrm{min}^{-1}$ until reaching each of the final heat-treatment temperatures: $120,140,160$, and $180^{\circ} \mathrm{C}$. The details of the heat treatment programs used are presented in Figure 2. 


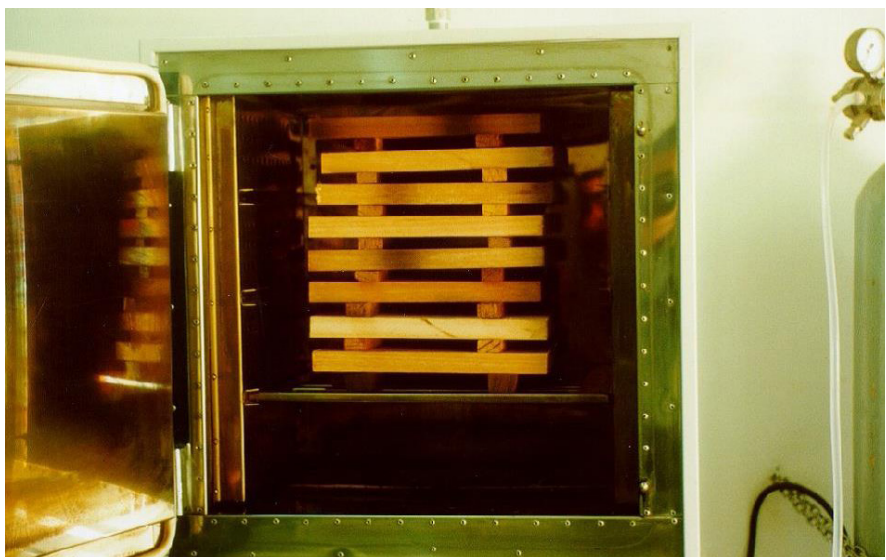

Figure 1: Arrangement of wood samples in electric oven (Source: Brito et al. 2006, with permission of Cerne journal).

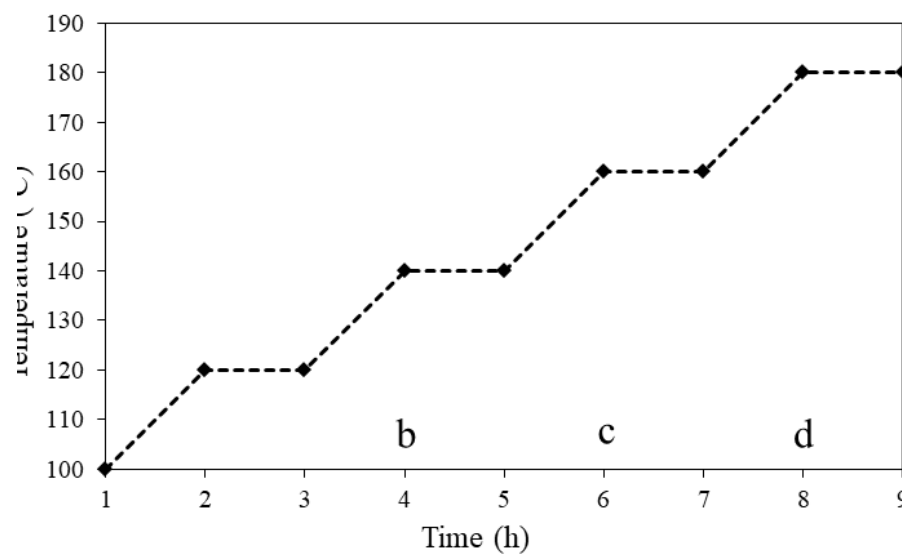

Figure 2: Heat-treatment programs $\left(\mathrm{a}=120^{\circ} \mathrm{C} ; \mathrm{a}+\mathrm{b}=140{ }^{\circ} \mathrm{C} ; \mathrm{a}+\mathrm{b}+\mathrm{c}=160{ }^{\circ} \mathrm{C} ; \mathrm{a}+\mathrm{b}+\mathrm{c}+\mathrm{d}=180{ }^{\circ} \mathrm{C}\right)$.

The treatments were based on information obtained in the literature (Brito et al. 2006, Brito et al. 2008), and at the end of each heat treatment, the oven was turned off for natural cooling to $30{ }^{\circ} \mathrm{C}$. The heat-treated materials were placed in a climatic test chamber for the moisture content stabilization to proceed the further proposed assays.

For each biological resistance test, ten boards of each species were selected with the following treatments:

- P0: Pinus wood not heat-treated.

- P120: Pinus wood heat-treated at $120^{\circ} \mathrm{C}$.

- P140: Pinus wood heat-treated at $140{ }^{\circ} \mathrm{C}$.

- P160: Pinus wood heat-treated at $160{ }^{\circ} \mathrm{C}$.

- P180: Pinus wood heat-treated at $180{ }^{\circ} \mathrm{C}$.

- E0: Eucalyptus wood not heat-treated.

- E120: Eucalyptus wood heat-treated at $120^{\circ} \mathrm{C}$.

- E140: Eucalyptus wood heat-treated at $140{ }^{\circ} \mathrm{C}$. 
- E160: Eucalyptus wood heat-treated at $160^{\circ} \mathrm{C}$.

- E180: Eucalyptus wood heat-treated at $180^{\circ} \mathrm{C}$.

\section{Resistance to white rot and brown rot fungi}

The resistance to white and brown rot fungi were evaluated according to the American standard Accelerated Laboratory Test of Natural Decay Resistance of Woods (ASTM, 2005). The samples with dimensions of 25 x $25 \times 9 \mathrm{~mm}$ were then exposed to pure cultures of fungi (white or brown rot). These samples of known weight and moisture content were placed in clean glass flasks containing sterile soil and fungus inoculum, shown in Table 1.

Table 1: Fungus used for the biological resistance assays.

\begin{tabular}{lcccc}
\hline & Unheated-SRT & Heated-SRT & Unheated-LRT & Heated-LRT \\
\hline Holocellulose (\%) & $67,36 \pm 2,53$ & $56,68 \pm 0,23$ & $67,49 \pm 0,45$ & $57,69 \pm 0,01$ \\
Cellulose (\%) & $41,10 \pm 2,48$ & $45,96 \pm 0,75$ & $39,89 \pm 1,97$ & $48,08 \pm 0,57$ \\
Hemicellulose (\%) & $26,26 \pm 2,48$ & $10,71 \pm 0,75$ & $27,60 \pm 1,97$ & $9,60 \pm 0,57$ \\
Lignin (\%) & $32,64 \pm 0,10$ & $43,32 \pm 0,67$ & $32,51 \pm 0,13$ & $42,31 \pm 0,20$ \\
\hline
\end{tabular}

According to ASTM-D-2017 (2005), the hardwood should be tested for resistance to three fungi, but the fungus Postia placenta did not grow on Eucalyptus samples, even after several attempts of inoculation. Thereby, it was disregarded in this study.

The glass flasks containing the samples and fungi were kept in the climate chamber at $27^{\circ} \mathrm{C}$ and relative humidity of $70 \pm 5 \%$ for fourteen weeks. After this period, the samples were removed from the flasks and washed in distilled water to remove the mycelia of fungi. Then, they were once again acclimated before being weighed again. The evaluation was performed to determine the percentage of mass reduction in relation to the initial mass.

\section{Resistance to soft rot fungi}

The resistance to soft rot fungi followed the method described by the Institute for Technological Research Laboratory Accelerated Assay for Determination of Preservatives Efficiency against Soft Rot Fungi (IPT 1980). Samples of $30 \times 15 \times 5 \mathrm{~mm}$ size were exposed to natural soil microflora for degradation over a sixteen-week period. After this period, the material was washed and placed in a climatic chamber to evaluate the percentage of mass loss in relation to the initial mass.

\section{Data analysis}

The data analysis used the statistical nonparametric Kruskal Wallis with $5 \%$ of significance, and when differences were detected, the Mann Whitney test for multiple comparisons of means was applied. The design considered five treatments for the heat treatments temperatures in each species (Pinus and Eucalyptus) and ten replicates per assay performed.

\section{RESULTS AND DISCUSSION}

The results of the brown rot in Pinus caribaea varied according to the final heat treatment temperature, as shown in Table 2 below. 
Table 2: Mass loss percentage of $P$. caribaea after biological assay for brown rot fungi resistance.

\begin{tabular}{ccc}
\hline \multirow{2}{*}{ Treatment } & \multicolumn{2}{c}{ Fungi } \\
\cline { 2 - 3 } & Gloeophyllum trabeum & Postia placenta \\
\hline P0 & $45,24^{\mathrm{bA}}{ }_{(20,44)}$ & $21,42^{\mathrm{bB}}{ }_{(19,20)}$ \\
P120 & $54,85^{\mathrm{aA}}{ }_{(12,29)}$ & $23,37^{\mathrm{bB}}{ }_{(15,11)}$ \\
P140 & $59,15^{\mathrm{aA}}{ }_{(5,01)}$ & $28,35^{\mathrm{aB}}{ }_{(21,45)}$ \\
P160 & $23,21^{\mathrm{cA}}{ }_{(19,94)}^{\mathrm{cB}}$ & $9,16^{\mathrm{cB}}{ }_{(12,05)}$ \\
\hline
\end{tabular}

Values followed by the same letter did not differ by Mann Whitney test at $95 \%$ probability $(p>0,05)$. Lowercase letters compare values between rows and capital letters compare values between columns. In parentheses are the standard deviations.

It was observed that the Pinus caribaea wood was more susceptible to fungal attack of Gloeophyllum trabeum than the Postia placenta, having greater weight loss in all the treatments.

When exposed to the fungus Gloeophyllum trabeum the Pinus wood showed greater weight loss for heat-treated woods at 120 and $140{ }^{\circ} \mathrm{C}$ and showed lower mass loss at 160 and $180{ }^{\circ} \mathrm{C}$. When in contact with the Postia placenta fungus, the $P$. caribaea samples also showed less weight loss when heat-treated to 160 and $180{ }^{\circ} \mathrm{C}$ and greater mass loss for the $140{ }^{\circ} \mathrm{C}$ treatment. The untreated samples showed intermediate values of mass loss in relation to heat treatments.

In general, Pinus caribaea woods in contact with both fungi showed similar behavior, having greater mass loss detected in treated samples at $140{ }^{\circ} \mathrm{C}$ and the lowest loss in heat-treated samples at $180^{\circ} \mathrm{C}$. In this case, the increase in susceptibility was approximately $70,31 \%$ to $75,38 \%$ for G. trabeum and P. placenta, respectively.

Modes (2010) observed a lower resistance of Pinus taeda and Eucalyptus grandis wood heat-treated at 130 and $160{ }^{\circ} \mathrm{C}$ with Gloeophyllum trabeum fungus. The author observed the same trend for white rot under action of Trametes versicolor in E. grandis.

In the same way, Doi et al. (2005) found greater susceptibility to the rotting of Larix leptolepis wood by the fungus Fomitopsis palistris for woods treated at 120 and $130{ }^{\circ} \mathrm{C}$. These variations in the mass loss can be associated with the production of fragments of low weight sugars molecules, resulting from the hemicellulose degradation during the thermal treatment processes at moderate temperatures of up to $160^{\circ} \mathrm{C}$. It is possible that fungal growth can be stimulated, not only by the resulting compounds from the decomposition of hemicellulose, but also by the removal of some extractives (Puls et al. 1985, Brito et al. 2006, Rocha 2011).

Table 3 shows the results for sample mass loss of Eucalyptus saligna wood subjected to white and brown rot assays.

Table 3: Mass loss percentage of E. saligna after biological assay for resistance to fungi.

\begin{tabular}{|c|c|c|}
\hline \multirow[b]{2}{*}{ Treatment } & \multicolumn{2}{|c|}{ Fungi } \\
\hline & Gloeophyllum trabeum ${ }^{I}$ & $\begin{array}{l}\text { Pycnoporus } \\
\text { sanguineus }^{2}\end{array}$ \\
\hline E0 & $9,78^{\mathrm{aB}}(11,94)$ & $32,76^{\mathrm{aA}}$ \\
\hline E120 & $0,73^{\mathrm{bB}}(2,26)$ & $35,49^{\mathrm{aA}}(14,81)$ \\
\hline E140 & $1,42^{\mathrm{bB}}(2,64)$ & $23,61^{\mathrm{bA}}(17,93)$ \\
\hline E160 & $1,33^{\mathrm{bB}}(2,27)$ & $27,71^{\mathrm{bA}}(18,05)$ \\
\hline E180 & $1,34^{\mathrm{bB}}(1,67)$ & $9,46^{\mathrm{cA}}(10,11)$ \\
\hline
\end{tabular}

\footnotetext{
${ }^{1}$ Fungus that causes brown rot, ${ }^{2}$ Fungus causing white rot. Values followed by the same letter do not differ by Mann Whitney test $95 \%$ probability $(p>0,05)$. Lowercase letters compare values between rows and capitals letters compare values between columns. In parentheses are the standard deviations.
}

Eucalyptus saligna was more susceptible to attack by white rot fungus than by brown rot fungus in terms of mass loss percentage, as compared between the same treatments for different fungi.

In general, eucalyptus woods showed more resistance when subjected to heat treatment, except for the 
E120 treatment under the action of the fungus $P$. sanguineus.

When under the action of G. trabeum, the largest mass loss detected for the E. saligna wood was in the E0 treatment (control), and the other treatments showed lower mass loss values. In this case, the E120 was already more resistant, presenting a reduction of $92,54 \%$ when compared with the mass loss by the control treatment.

The lowest mass loss under attack of Pycnoporus sanguineus to E. saligna was observed for the wood treated at a temperature of $180{ }^{\circ} \mathrm{C}$, which presented a reduction of $73,34 \%$ in relation to the E120 treatment. For this same fungus, the E0 treatments (control) and E120 showed higher weight loss than others treatments, and the mass loss of E140 and E160 treatments showed intermediate values among the treatments.

In absolute figures, the results for mass loss of Eucalyptus saligna wood presented below those measured for Pinus caribaea in all treatments when exposed to the same fungus (G. trabeum).

According to Figure 3, which shows the results for soft rot, it was observed that both woods, Pinus caribeae and Eucalytptus saligna, showed lower mass loss for samples treated at higher temperatures (160 and $\left.180{ }^{\circ} \mathrm{C}\right)$.

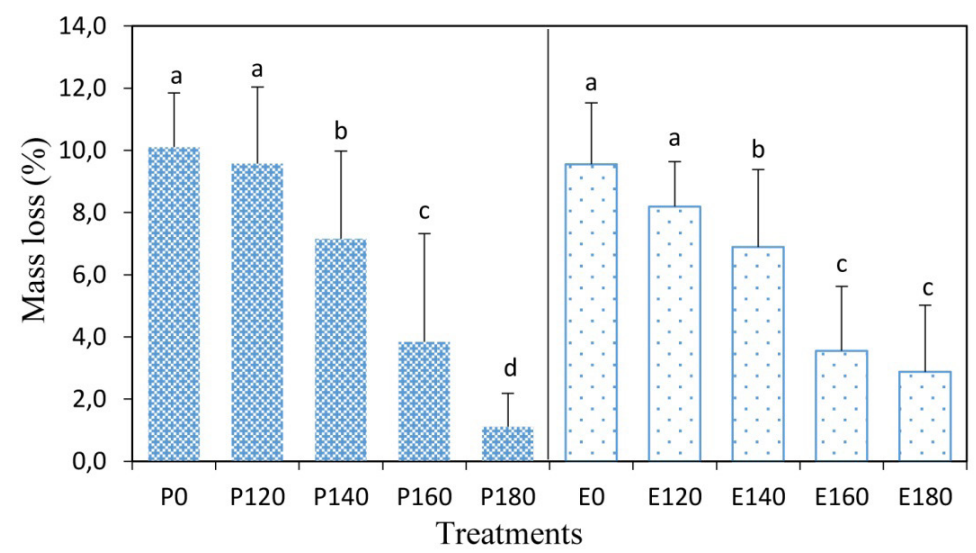

Figure 3: Wood mass loss (\%) after biological resistance assay for soft rot. Values followed by the same letter did not differ by Mann Whitney test $95 \%$ probability ( $p>0,05)$, considering the same species of wood $(\mathrm{p}>0,05)$.

For soft rot, samples of Pinus wood at $180^{\circ} \mathrm{C}$ and Eucalyptus in 160 and $180^{\circ} \mathrm{C}$ had lower mass loss. Both woods did not present differences between the control and $120^{\circ} \mathrm{C}$ treatment.

\section{CONCLUSIONS}

The best results for rot resistance of Pinus caribaea wood were in samples heat-treated at higher temperatures $\left(160\right.$ and $\left.180^{\circ} \mathrm{C}\right)$.

The Eucalyptus saligna wood showed increased resistance to the fungus Gloeophyllum trabeum for all treatments. In addition, E. saligna showed greater resistance to fungus Pycnoporus sanguineous and soft rot fungus for the treatments with temperatures greater than $120^{\circ} \mathrm{C}$.

The heat treatment process may be used as an alternative for wood preservation. However, further studies are recommended to check the changes in the physical and mechanical properties.

\section{ACKNOWLEDGMENTS}

Thanks to companies Duratex and Eucatex for the materials, to the Coordination for the Improvement of Higher Education Personnel (CAPES) and the Forestry Science and Research Institute (IPEF) for the students 
grants. We would also like to thank Michael James Stablein of the University of Illinois Urbana-Champaign for his translation services and review of this work.

\section{REFERENCES}

Alén, R.; Kotilainen, R.; Zaman, A. 2002. Thermochemical behavior of Norway spruce (Picea abies) at $180-225^{\circ}$ C. Wood Science and Technology 36(2): 163-171.

ASTM. American Society for Testing and Materials. 2005. Standard test method for accelerated laboratory test of natural decay resistance of wood. ASTM D-2017. Philadelphia, 5p.

Batista, D.; Muñiz, G.I.; Da Silva, J.T.; Paes, J.; Nisgoski, S. 2016. Effect of the Brazilian thermal modification process on the chemical composition of Eucalyptus grandis juvenile wood: Part 1: Cell wall polymers and extractives contents. Maderas-Cienc Tecnol 18(2):273-284.

Brito, J.O. 1992. Estudo das influências da temperatura, taxa de aquecimento e densidade da madeira de Eucalyptus maculata e Eucalyptus citriodora sobre os resíduos sólidos da pirólise. Piracicaba. Ph.D. Thesis (Livre Docência) - Escola Superior de Agricultura “Luiz de Queiroz”, Universidade de São Paulo. p. 81.

Brito, J.O.; Silva, F.G.; Leão, M.M.; Almeida, G. 2008. Chemical composition changes in Eucalyptus and Pinus woods submitted to heat treatment. Bioresource Technology 99(18): 8545-8548.

Brito, J.O.; Garcia, J.N.; Bortoletto JR, G. 2006. Densidade básica e retratibilidade da madeira de Eucalyptus grandis submetida a diferentes temperaturas de termorretificação. Cerne 12(2): 182-188.

Doi, S.; Aoyama, M.; Yamauchi, S.; Kurimoto, Y. 2005. Changes of decay and termite durabilities of Japanese larch (Larix leptolepis) wood due to high-temperature kiln drying processes. Journal of Wood Science 1(5): 526-530.

Ferrarini, S.F.; Santos, H.S.; Miranda, L.G.; Azevedo, C.M.N.; Pires, M.J.R.; Maia, S.M. 2012. Classification of waste wood treated with chromated copper arsenate and boron/fluorine preservatives. Quimica Nova 35(9): 1767-1771.

Garcia, R.A.; Carvalho, A.M.; Latorraca, J.V.F.; Matos, J.L.M.; Santos, W.A.; Silva, R.F.M. 2012. Nondestructive evaluation of heat-treated Eucalyptus grandis Hill ex Maiden wood using stress wave method. Wood Science and Technology 46(1): 41-52.

Instituto de Pesquisas Tecnológicas. IPT. 1980. Ensaio acelerado de laboratório para a determinação da eficiência de preservativos contra fungos da podridão-mole. São Paulo: IPT/DIMAD. 1. 1157, 2p.

Metsä-Kortelainen, S.; Anitikainen, T.; Viitaniemi, P. 2005. The water absorption of sapwood and heartwood of Scots pines and Norway spruce heat-treated at $170^{\circ} \mathrm{C}, 190^{\circ} \mathrm{C}, 210^{\circ} \mathrm{C}$ and $230^{\circ} \mathrm{C}$. Holz als Rohund Werkstoff 64(3):192197.

Modes, K.S. 2010. Efeito da retificação térmica nas propriedades físico-mecânicas e biológica das madeiras de Pinus taeda e Eucalyptus grandis. MSc. Thesis. Universidade Federal de Santa Maria, 99p. $<$ https://repositorio.ufsm.br/bitstream/handle/1/8669/MODES\%2c\%20KARINA\%20SOARES.pdf?sequen-

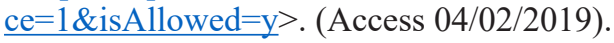

Palermo, G.P.M.; Latorraca, J.V.F.; Moura, L.F.; Nolasco, A.M.; Carvalho, A.M.; Garcia, R.A. 2015. Surface roughness of heat treated Eucalyptus grandis wood. Maderas-Cienc Tecnol 16(1): 03-12.

Pincelli, A.L.P.S.M.; Brito, J.O.; Corrente, J.E. 2002. Avaliação da termorretificação sobre a colagem na madeira de Eucalyptus saligna e Pinus caribaea var. hondurensis. Scientia Forestalis 61(3): 122-132.

Poletto, M. 2017. Assessment of the thermal behavior of lignins from softwood and hardwood species. Maderas-Cienc Tecnol 19(1): 63-74. 
Puls, J.; Poutanen, K.; Körner, HU.; Viikari, L. 1985. Biotechnical utilization of wood carbohydrates after steaming pretreatment. Applied Microbiology and Biotechnology 22(6): 416-423.

Rocha, C.D. 2011. Efeito da vaporização na madeira de Eucalyptus grandis sobre as suas propriedades químicas e resistência natural a fungos e cupins. MSc. Thesis. Universidade Estadual Paulista. Botucatu-SP. 121p. $<$ https://repositorio.unesp.br/bitstream/handle/11449/99760/rocha cd me botfca.pdf? sequence=1\&isAllowed $=\mathrm{y} \geq$. (Access 04/02/2019).

Rousset, P.; Perré, P.; Girard, P. 2004. Modification of mass transfer properties in poplar wood ( $P$. robusta) by thermal treatment at high temperature. Holz als Roh- und Werkstoff 62(2): 113-119.

Vivian, M.A.; Santini, E.J.; Modes, K.S.; Garlet, A.; Morais, W.W.C. 2015. Resistência biológica da madeira tratada de Eucalyptus grandis e Eucalyptus cloeziana a fungos apodrecedores em ensaios de laboratório. Ciência Florestal 25(1): 175-183.

Weiland, J.J.; Guyonnet, R. 2003. Study of chemical modifications and fungi degradation of thermally modified wood using DRIFT spectroscopy. Holz als Roh-Werkstoff 61(2): 216-220.

Wikberg, H.; Maunu, S.L. 2004. Characterization of thermally modified hard and softwoods by 13C CPMAS NMR. Carbohidrate Polymers 58(4): 461-466. 